\title{
Visitor Satisfaction and Tourist Attraction Image
}

\author{
B.O.Y. Marpaung ${ }^{1} \&$ Felicia Tania ${ }^{2}$ \\ ${ }^{1}$ Architecture Department, Faculty of Engineering, Universitas Sumatera Utara, Indonesia \\ ${ }^{2}$ Independent Researcher, Pekanbaru, Riau, Indonesia \\ Correspondence: B.O.Y. Marpaung, Jalan Perpustakaan Universitas Sumatera Utara, Padang Bulan, Kecamatan \\ Medan Baru, Kota Medan, Sumatera Utara Indonesia, 20155.
}

Received: March 22, 2021

Accepted: April 19, 2021

Online Published: April 23, 2021

doi:10.5539/ijps.v13n2p33

URL: https://doi.org/10.5539/ijps.v13n2p33

\begin{abstract}
Tourist destination image is formed through tourists' perception, which is significantly influenced by interrelated factors related to tourists and the tourist destination itself, i.e., travel motivation, service quality, and tourist satisfaction. The object of this research is the Parapat city in Simalungun Regency North Sumatra Province of Indonesia. Parapat in Simalungun Regency, as a high potential tourist destination in North Sumatera Province of Indonesia, must be able to create a positive image to increase the number of tourist visits. The purpose of this study is to analyze the direct and indirect influence of tourists' motivation to travel, service quality, and tourist satisfaction towards the image of Parapat. This study suggests a tourist development strategy through the formation of Parapat positive destination image from tourist's perspective, hence will provide benefits for Parapat tourism stakeholders in developing and managing tourist destinations by improving the quality of existing functional aspects.
\end{abstract}

Keywords: destination, image, motivation, quality, satisfaction

\section{Introduction}

Tourism has rapidly grown in recent years, as travelling becomes a phenomenon in society as a necessity and thus inseparable from human life. Through travel activities, the tourism industry contributes to various sectors, mainly towards the economy, by increasing foreign exchange and providing business opportunities to improve local communities' life quality. Tourists can evaluate a tourist destination based on the interpretation of their beliefs and perception, which is then referred to as the destination image. The image established by a tourist destination is often regarded as a critical aspect in tourist destination development. It is influential towards tourists' decision-making to travel to the related tourist destination. Although the previous tourism studies primarily investigated these issues related to destination image independently, very limited research addressed the interrelationships between tourists' motivation to travel, quality of service provided by tourist destination, and tourist's satisfaction in shaping a particular tourist destination's image. Researchers discussed the existing literature related to each construct and the interrelationships among the concepts through this research.

Parapat in Simalungun Regency, North Sumatera Province, has a high potential in the tourism industry as it offers a variety of tourist destinations, particularly nature-based destinations. Based on report analysis of Simalungun Regency's tourist destinations in 2017-2018, Parapat becomes the most-visited tourist destination in Simalungun Regency. However, there is a significant decrease in total visits from 142.895 tourists (2017) to 67.518 tourists (2018) in one year. Due to the increasingly competitive tourism market, every tourist destination must strive to maximize the destination's appeal in the targeted market. To sustain the competitive business in the tourism industry, Parapat tourism stakeholders must establish a positive and unique image to increase tourist visits. In accordance with research problems, the purpose of this study, i.e., (1) to identify tourist destinations that tourists frequently visit in Parapat, (2) to analyze the influence of travel motivation towards the image of Parapat, (3) to analyze the influence of service quality towards the image of Parapat, (4) to analyze the influence of tourist satisfaction in forming an image of Parapat, and (5) to observe the influence of motivation, service quality, and tourist satisfaction directly and indirectly towards the image of Parapat. 


\section{Literature Review}

\subsection{Tourist Destination}

A tourist destination must have several complementary attributes as these attributes are required by tourists to support their travel experience. According to Suwena (2010), there are four main attributes in a tourist destination known as "4A", i.e., (1) attraction (complementary element in a tourist destination that includes natural resources, human-made, culture or other aspects that evokes tourist's motivation to travel); (2) amenities (facilities and services provided to fulfill tourist's travel needs, consisting accommodation, food and beverage providers, shopping and entertainment venues); (3) accessibility (ease of tourist's access to/within tourist destination which related to cost and comforts); and (4) ancillary (the involvement of tourism stakeholders as human resources that manages tourist destination to provide positive and memorable tourism experience for tourists).

From a marketing perspective, tourism destination attributes are designed to appeal to tourists and marketed as a solution to fulfill tourists' needs and demands to increase the competitiveness of the particular tourist destination (Visser, 2009). To attract tourists, tourist destination stakeholders should provide products and services that fulfills or even exceed tourists' demands compared to other tourist destinations. Tourism promotion manifested the tourist destination image through official promotional media or word-of-mouth from past travelers (Akroush \& Jraisat, 2016). Although a tourist destination is well-managed by stakeholders, tourist destination development relies heavily on tourism promotion as a strategy that involves destination image in shaping the initial depiction or perception of potential tourists towards the tourist destination. Tourism promotion typically uses various external information sources. An effective tourism promotion should also include information about the tourist destination's attractiveness and qualities, e.g., accommodations provided, atmosphere offered, cost-appropriateness.

In recent years, communication media has been an effective tool for tourism stakeholders to promote tourist destinations. Tourists also publish their travel experiences to help encourage destination tourist attractions (Katsoni, 2014). In today's era of globalization, information distribution through various forms of communication media becomes an effective tourism marketing strategy to generate interest and motivate potential tourists to travel. As a significant stakeholder in the tourism industry, the local government has to manage the promotion of tourist destinations. The role of tourists who visited the tourist destination is also significant, as earlier studies related to tourist's post-consumption behavior suggest that past travelers can directly influence potential tourists to visit or decline their intention to travel to the tourist destination.

\subsection{Destination Image}

Destination image comprises the beliefs, ideas, and impressions perceived by travelers towards the tourist destination (Kotler \& Keller, 2009). As a person's portrayal of a tourist destination, destination image plays a vital role in tourism development. The overall appearance of a tourist destination is formed by cognitive image and affective image, in which cognitive image reflects traveler's knowledge, recognition, beliefs, thoughts, and awareness towards each attribute of the tourist destination. In contrast, the affective image represents feeling and perception as a tourist's emotional interpretation towards a tourist destination (Beerli \& Martin, 2004). The process of establishing a destination image by tourists through tourism experience, according to Manhas, Manrai \& Manrai (2016), can be described in three stages, i.e., pre-consumption stage (travel planning), consumption stage (travel implementation), and post-consumption stage (after travel). Tourists will shape the overall image of a tourist destination based on their travel experience.

\subsection{Travel Motivation}

Travel motivation is considered a determinant for tourists to travel to fulfill their needs. Travel motivation is the 'trigger' of the travel process as the travel motivation determines the potential tourists in travel decision-making and which tourist destination will be visited (Pitana \& Gayatri, 2005). An intention to travel is formed by various reasons that arose in potential tourists' lives, thus encouraging them to fulfill their needs by travelling. Jang, Bai, $\mathrm{Hu} \& \mathrm{Wu}(2009)$ suggested two factors as an approach to assess travel motivation, i.e., push factors (internal stimuli) and pull factors (external stimuli). From a tourist's perspective, the overall factors form a strong travel motivation that determines the tourist's decision-making process to travel to a particular tourist destination. In other words, tourists are more likely to choose a destination that is believed to fulfill their internal needs.

Gnanapala (2012) stated that push factor represents internal factors that encourage the emergence of one's desire to travel, so that push factors can also be referred to as a set of intangible factors forming travel motivation, i.e., 
(1) escape (the desire to escape from tense or tiring routine temporarily), (2) rest \& relaxation (the desire to rest or to improve physical and cognitive state), (3) prestige (the desire to improve social status by travelling publication for others to see), (4) enhancement of kinship relationship (the desire to strengthen relationships among family members who travel together), and (5) adventure (the desire to explore a tourist destination directly, in order to enrich their knowledge and experience of the new places).

Gnanapala (2012) also suggests a set of external factors in the form of tourist destination attributes that attracts one's interest to travel so that the pull factors can also be referred to as a set of tangible factors forming travel motivation, i.e., (1) attractions (uniqueness of tourist destination including the natural resources, cultural, human-made or other aspects that can pull tourists to visit), (2) budget (inexpensive travel expenses following travel experience quality), (3) culture (cultural property owned by tourist destination that is usually presented through live cultural performances or surrounding infrastructure), and (4) amenities (the convenient service and attractive facilities provided by the tourist destination developer).

From the service provider's perspective, travel motivation is regarded as the primary consideration in providing services according to tourist's expectations to build tourist satisfaction (Setyaningsih, 2017). A person travels because of their encouragement to fulfill particular desires/objectives. The diversity of travel motivation has an impact on different tourist's needs. Thus, the tourist destination development planner must understand tourist's travel motivation to provide services that can fulfill various tourist needs. If tourists are satisfied with the services offered, they will most likely form a positive image towards the tourist destination

\subsection{Service Quality}

Service quality as part of the travel process's consumption stage reflects the fulfillment of products/services by service providers towards tourists' needs and the accuracy in conveying service to fulfill tourists' expectations (Tjiptono, 2008). The success of a tourist destination depends significantly on the service provider's efforts in providing high-quality service to tourists. The approach in evaluating the quality of services, according to Zeithami and Bitner (2010), is divided into 5 SERVQUAL dimensions, i.e., (1) assurance (the ability of service providers to generate trust towards tourists, which is free from risk or doubt through guaranteed high-quality services), (2) empathy (the ability of service providers to pay attention individually and understanding the needs of tourists so that tourists feel valued as guests), (3) reliability (the ability of service providers in professionally delivering services as expected by tourists), (4) responsiveness (participation and responsivity that the service provider must have to serve the tourists), and (5) tangibles (the form of physical facilities to support other intangible services).

Tourists' perception and evaluation towards service quality determine the satisfaction that tourists feel, as high-quality service tends to increase tourist satisfaction towards travel destination (Khuong \& Phuong, 2017). Service providers' efforts to provide high-quality and suitable service plays a significant role in establishing tourist satisfaction; hence, tourists will directly form a positive image of the related tourist destination because they have received satisfactory service.

\subsection{Tourist Satisfaction}

Chen \& Tsai (2007) stated that tourist satisfaction is a form of tourist's pleasure as positive emotion arises from their travel experience based on the fulfillment of their expectations or travel needs. Satisfaction is measured over the performance of products and services in a tourist destination so that tourist will be delighted if the products and services provided can fulfill tourist's needs. From a tourist's behavioral perspective, the satisfaction level results from the post-consumption stage in the travel process. Tourists will be delighted when service providers can provide products and services more than expected by tourists (Tjiptono, 2014). The gap between tourist's expectations and amenities performance determines the level of tourist satisfaction, so tourist destination development planners should provide services that exceed tourists' expectations. Thus tourists can achieve high satisfaction. Tourist satisfaction indicates how well a tourist destination is currently meeting tourists' needs related to the quality of product and services received by tourists, which significantly influences tourists in shaping a positive image towards the tourist destination (Martaleni, 2017). The higher the level of tourist satisfaction, the higher the positive image formed by tourists towards tourist destination, and vice versa. Tourist satisfaction serves as feedback for tourist destination development planners by evaluating the tourism attributes periodically and improving the quality of products and services to meet the needs of future tourists.

Tourist satisfaction is considered a critical element to maintain competitive business as a benchmark of successful tourism marketing because it is directly associated with the potential of revisit and travel decision-making towards a particular tourist destination (Meng, Tepanon, \& Uysal, 2008). When a tourist destination can provide a unique and memorable destination image, the impression will evoke tourists' intention 
to revisit in the future. A positive destination image can be recommended to outside parties through the influence of word-of-mouth. Hence, they will be motivated to travel to the related tourist destination.

\section{Method}

In completing this research, researchers used the multiphase mixed method by first conducted observations based on each attribute of 7 Parapat tourist destinations through a field survey to identify which tourist destinations are frequently visited by tourists in Parapat. Researchers also distributed questionnaires to respondents to collect data simultaneously regarding the information sources, travel motivation, service quality and tourist satisfaction. Respondents are a random sample of 115 local tourists aged 17-30 years who is currently travelling/had travelled to Parapat. The data obtained from the questionnaire are qualitative data in the form of answers to substantial questions and quantitative data in the form of tourist evaluation towards several indicators using a 5-point Likert scale ranging between 5 as 'strongly agree' to 1 as 'strongly disagree' for service quality, and between 5 as 'highly satisfied/highly positive' to 1 as 'dissatisfied/negative' for tourist satisfaction and destination image. Quantitative data was used because it supports the accuracy of qualitative data. During the final stage, researchers analyzed the direct and indirect influence of motivation, service quality and tourist satisfaction towards the image of tourist destinations in Parapat. Previous studies often investigated these issues related to destination image independently without discussing each construct's interrelationship (e.g., Khan, Chelliah, \& Ahmed, 2017; Kayat \& Hai, 2014; Chi \& Qu, 2008). Although the usage of a mixed-method in tourism literature has been limited, this method's strength has been proven in helping researchers connect several seemingly independent studies to achieve the overall research goal (Lattimore, Mura, \& Yung, 2017).

\section{Results and Discussions}

\subsection{Tourist Destinations in Parapat}

\section{Attraction}

Every tourist visited at least 1 out of 7 tourist attractions when they come to Parapat (figure 1) because each tourist attraction in Parapat has its unique value. As one of the world's natural wonders, Lake Toba becomes the leading tourist attraction in Parapat. Parapat is widely known by local and foreign tourists as it offers the enchanting beauty of nature. The surrounding hills and Samosir Island in the middle of the lake make it a uniqueness that only had by Lake Toba. Lake Toba also offers annual cultural events, such as Toba Lake Festival and other cultural performances by Parapat's local tribe, Batak. Besides Lake Toba, four beaches in Parapat, i.e., Pasir Putih Beach, Inna Parapat Beach, Indah Permai Beach, and Free Beach overlooking Lake Toba, offer a splendid natural view. Parapat is also famous for its other two human-made attractions, i.e., Pesanggrahan Bung Karno House, with high historical value because it was once a place of exile for Ir. Sukarno (first president of Indonesia) during the colonial era; and HKBP Parapat Church as a church with high religious value offers splendid facade as a blend of traditional Batak ornaments and modern architectural style. Hence, Parapat is well known for its diversity of attractions, incredibly natural and cultural attractions. 


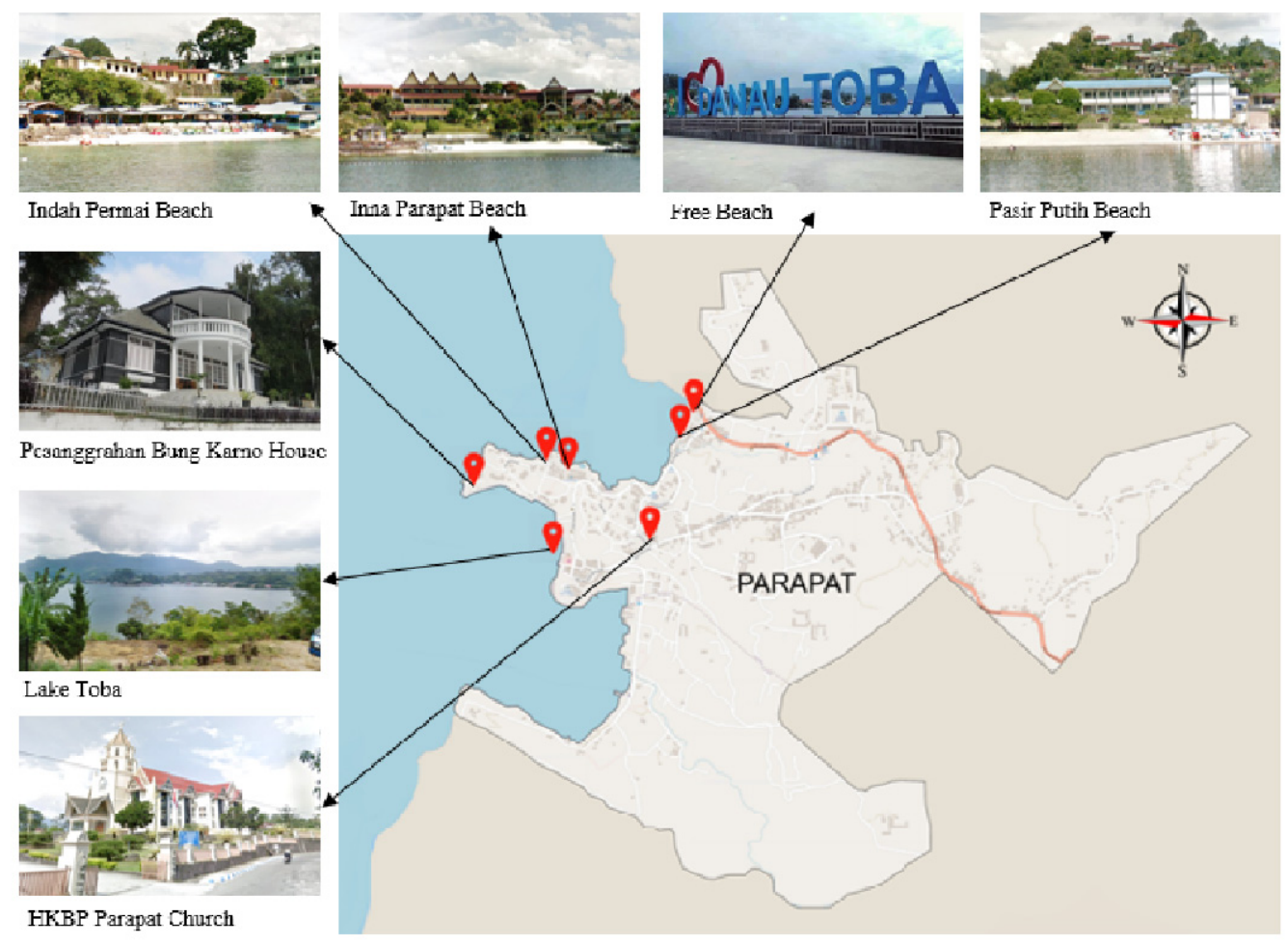

Figure 1. The tourist destinations in Parapat

\section{Amenities}

The amenities provided at Parapat tourist attractions are pretty complete and able to accommodate tourists. Out of 223 visits from 115 questionnaires distributed, Lake Toba (49.6\%), Pasir Putih Beach (14.7\%), and Inna Parapat Beach (14.7\%) are the most frequently visited tourist attractions by tourists in Parapat, as these three tourist attractions provide more accommodation compared to other Parapat tourist attractions. Every tourist attraction in Parapat provides amenities consisting hotel, restaurant, church, mosque, and tourist facilities (water sports for Lake Toba and Parapat beaches). Souvenir shops are also available near some tourist attractions in Parapat. However, tourism stakeholders should provide more tourist-related facilities in Indah Permai Beach, Free Beach, Pesanggrahan Bung Karno House, and HKBP Parapat Church from the availability of amenities.

\section{Accessibility}

Although some tourist attractions are difficult to reach by tourists, the infrastructure of roads in Parapat is wide enough to be passed by two cars, and the condition of an asphalt surface is well maintained. Thus, tourists are given ease in reaching tourist attractions in Parapat. Next to the road is a pedestrian pavement equipped with street lights that supports pedestrian circulation. However, these are not available on local roads near Indah Permai Beach and Pesanggrahan Bung Karno House. There are plenty of transportation options for tourists in Parapat. Land transportation allows tourists to reach tourist attractions by public transit through Sosor Baba Terminal or private vehicles. Two ports support water transportation, i.e., Ajibata Port and Tigaraja Port. These ports are the main access point for tourists to reach Samosir Island from Parapat, and vice versa. Tourists can also explore the beauty of Lake Toba and beaches in Parapat directly using the tourist boats that stop at both ports. The overall accessibility in Parapat has a good evaluation in tourist's eye, as it supports both vehicle and pedestrian circulation.

\section{Ancillary}

As a Parapat tourism stakeholder, the government provides security facilities (CCTV and guardhouse/police office) and hygiene facilities (cleaning service and trash bin) to support travel activities in every Parapat tourist attractions. The local community is involved in maintaining each tourist attraction's hygiene and security in Parapat, although a guardhouse does not facilitate HKBP Parapat Church. The hospital as a health facility is located near Pasir Putih Beach and Free Beach. Realizing Parapat tourism's importance, the local government also provides tourism information centre and tour guide services as the leading ancillary service to support Parapat tourist attractions. 


\section{Tourist destination attributes analysis}

From a marketing perspective, tourism destination attributes are designed to appeal to tourists and marketed as a solution to fulfill tourists' needs and demands to increase the competitiveness of the particular tourist destination (Visser, 2009). Parapat tourist attractions are well managed in terms of attributes, supported by the ease of accessibility given to tourists and direct involvement of tourism stakeholders in providing ancillary services. Tourism marketers must still improve the quality and add more tourist facilities so that the appealing tourism attributes can attract more tourists to visit Parapat.

\section{Study of information related to Parapat tourism}

Based on table 1, most respondents (63.5\%) visited Parapat tourist attractions because they were given recommendations by past travelers who had visited Parapat. Through electronic media $(28.7 \%)$ and printed media $(1.7 \%)$, tourism promotion can attract tourists to visit Parapat. The remaining $6.1 \%$ of respondents visited Parapat because of other reasons that were not considered pull factors. In recent years, communication media has been an effective tool for tourism stakeholders to promote tourist destinations. Tourists also publish their travel experiences to help encourage destination tourist attractions (Katsoni, 2014). In recent years, Parapat tourism marketers have been promoting Parapat tourism through the internet (electronic media). It effectively reaches a bigger audience, including the distribution of digital posters and brochures, social media promotions, and articles on tourism websites, and tourism promotion videos. Recommendations given by past travelers who had visited Parapat has proven to be the most effective form to promote Parapat's initial image towards potential tourists, which can be conveyed directly through word-of-mouth or indirectly through communication media. This fact implies that Parapat tourism stakeholders must always strive to improve tourists' travel experience so that tourists want to give out the recommendation to potential tourists.

The number of local tourists was 119,756 people, and foreign tourists were 13,218 people that visited Parapat in 2019. This fact indicates that tourism promotions carried out mainly through broadcast media for the past few years have promoted Parapat tourism more quickly and effectively. However, the number of international visits was still deficient compared to domestic visits, proving that the current tourism marketing strategy was not sufficiently appealing for foreign tourists. The current Parapat tourism promotion focuses only on Lake Toba, which has the most outstanding natural potential in North Sumatra. Aside from improving promotions through communication media, other tourist destinations in Parapat and the attributes should also be marketed. This strategy can attract more potential tourists as they become aware of Parapat's various attractions and convince them in their travel decision-making.

Table 1. Information sources regarding Parapat tourism

\begin{tabular}{lll}
\hline Information sources & Frequency & Percentage (\%) \\
\hline Recommendation from past travelers & 73 & 52.1 \\
Communication media & 33 & 35.7 \\
Tourism brochures & 2 & 5.2 \\
Others & 7 & 7 \\
\hline
\end{tabular}

\subsection{Tourists Travel Motivation towards Image of Parapat}

\section{Push factors}

The desire for relaxation (35.7\%), escape from the daily routine (28\%), and explore new places $(26 \%)$ are the dominant push factors encouraging 115 Parapat tourists to travel (table 2). 19\% of respondents travelled to strengthen relationships between family members, and $0.9 \%$ travel on social media. They travelled to improve social status through the publication of travel on social media. Push factor represents internal factors that encourage the emergence of one's desire to travel, which can also be referred to as a set of intangible factors forming travel motivation (Gnanapala, 2012). Tourists seek tourist destinations in Parapat to fulfill their travel needs, mainly through amenities that accommodate most tourists' desire to relax and rest. Tourists feel refreshed because Parapat offers fresh air surrounded by nature. Some considered Parapat a temporary escape from the tension they face every day because tourist facilities (i.e., water bikes and boats) provided on Parapat beaches can provide cognitive and physical refreshment. A variety of Parapat attractions triggers tourist's curiosity to explore Parapat tourist destinations furthermore. Push factors are closely related to tourist's internal needs or desires that tourists must fulfill through various travel activities in Parapat. 


\section{Pull factors}

The attraction offered (45\%), the inexpensive travel budget (25.2\%), and the high cultural value owned $(23.5 \%)$ by Parapat's tourist destinations are the dominant pull factors attracting 115 respondents to visit Parapat (table 2). $5.2 \%$ of respondents travelled because of the exciting facilities and services offered by Parapat tourist destinations. Pull factors represent a set of external factors in tourist destination attributes that attract one's interest to travel, also referred to as tangible factors forming travel motivation (Gnanapala, 2012). Each tourist attractions in Parapat offers its attractiveness as the primary determinant for most tourists to travel to Parapat. The inexpensive travel budget could also attract many tourists to visit Parapat because the travel cost is considered affordable/worthy of amenities provided and ease of accessibility in Parapat. Pull factors are closely related to Parapat tourism attributes appealing to attract tourists to come to Parapat.

Table 2. Parapat tourists' travel motivation

\begin{tabular}{lll}
\hline Factors & Frequency & Percentage (\%) \\
\hline Pull factors & 41 & \\
Rest \& relaxation & 28 & 35.7 \\
Escape & 26 & 24.3 \\
Adventure & 19 & 22.6 \\
Enhancement of kinship relationship & 1 & 16.5 \\
Prestige & & 0.9 \\
Push factors & 45 & \\
Attraction & 29 & 39.1 \\
Budget & 27 & 25.2 \\
Culture & 6 & 23.5 \\
Amenities & 8 & 5.2 \\
Others & & 7 \\
\hline
\end{tabular}

\section{Travel Motivation Analysis}

Travel motivation is considered a determinant for tourists to travel to fulfill their needs. Travel motivation is the 'trigger' of the travel process as the travel motivation determines the potential tourists in travel decision-making and which tourist destination will be visited (Pitana \& Gayatri, 2005). From tourist behavior, the linkage between push factors and pull factors formed a strong sense of motivation to travel. Tourists decided to visit Parapat because they believed Parapat tourist destinations could provide a pleasant travel experience that meets tourists' needs. Thus, Parapat must always strive to improve amenities quality to fulfill various tourists' needs. Variety of attractions and affordable travel costs are a plus value of Parapat tourism, so the stakeholders must improve each attribute's quality in Parapat tourist destinations. Hence, tourists' expectations towards Parapat will be fulfilled, and tourists enjoy their trip in Parapat.

From the service provider's perspective, travel motivation is the primary consideration in providing services according to tourist's expectations to build tourist satisfaction (Setyaningsih, 2017). The diversity of Parapat tourists' travel motivation impacts on the different travel needs of each tourist. The overall services provided in Parapat tourist destinations were able to accommodate most of tourist's needs fulfillment of tourist's travel needs indicates the formation of tourist satisfaction. Parapat tourism services were able to fulfill most Parapat tourist's expectations; hence they perceived satisfaction and a positive image towards Parapat. Tourist's travel motivation indirectly determines the idea of the Parapat through service quality that can form tourist's satisfaction (figure 2). Accordingly, Parapat tourism stakeholders must improve the quality and suitability of services in Parapat towards a variety of tourists' travel motivation factors to improve the image of Parapat tourist destinations. 
Push factors

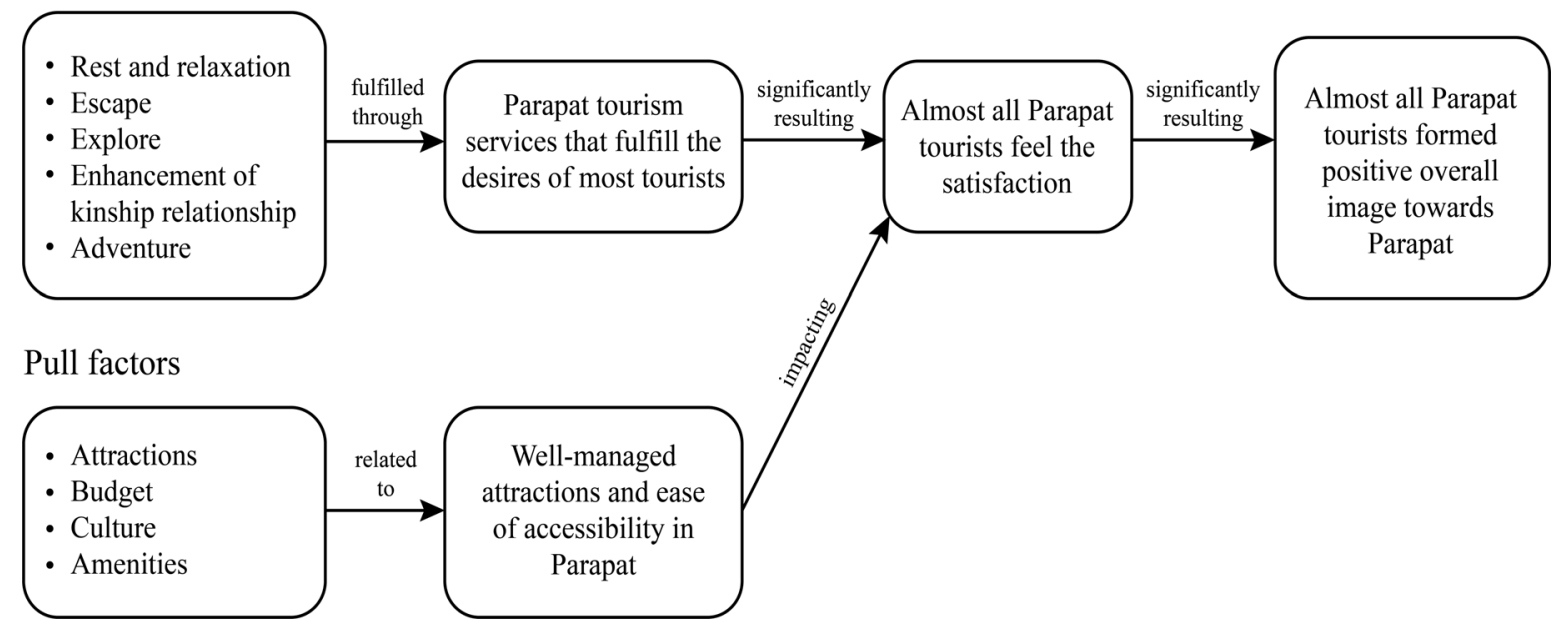

Figure 2. The influence of tourist's travel motivation towards the image of Parapat

\subsection{Service Quality towards the Image of Parapat}

The approach in evaluating the quality of services, according to Zeithami and Bitner (2010), is divided into five dimensions, i.e., (1) assurance (the ability of service providers to generate trust towards tourists, which is free from risk or doubt through guaranteed high-quality services); (2) empathy (the ability of service providers to pay attention individually and understanding the needs of tourists so that tourists feel valued as guests); (3) reliability (the ability of service providers in professionally delivering services as expected by tourists); (4) responsiveness (participation and responsivity that the service provider must have to serve the tourists); and (5) tangibles (the form of physical facilities to support other intangible services). Service quality dimensions from the observations of Parapat tourists are as shown in table 3 below.

Table 3. Parapat tourism service quality evaluation

\begin{tabular}{|c|c|c|c|c|c|c|}
\hline \multirow{2}{*}{ Aspect } & \multicolumn{5}{|c|}{ Frequency of Responses } & \multirow{2}{*}{ Mean } \\
\hline & 5 & 4 & 3 & 2 & 1 & \\
\hline \multicolumn{7}{|l|}{ Assurance } \\
\hline $\begin{array}{l}\text { Excellent knowledge and skills of service providers in } \\
\text { serving tourists }\end{array}$ & 24 & 41 & 45 & 5 & 0 & 3.7 \\
\hline $\begin{array}{l}\text { The quality of services provided by service providers to } \\
\text { tourists is suitable with the tourism promotion }\end{array}$ & 25 & 42 & 42 & 6 & 0 & 3.7 \\
\hline \multicolumn{7}{|l|}{ Empathy } \\
\hline Service providers are attentive towards every tourist & 19 & 47 & 43 & 5 & 1 & 3.7 \\
\hline $\begin{array}{l}\text { Service providers are sensible in recognizing specific } \\
\text { tourist's needs }\end{array}$ & 17 & 44 & 45 & 9 & 0 & 3.6 \\
\hline $\begin{array}{l}\text { Service providers are sincerely willing to solve problems } \\
\text { encountered by tourists }\end{array}$ & 12 & 39 & 52 & 12 & 0 & 3.4 \\
\hline \multicolumn{7}{|l|}{ Reliability } \\
\hline $\begin{array}{l}\text { High speed, accuracy and suitability of service given to } \\
\text { tourists }\end{array}$ & 11 & 45 & 48 & 11 & 0 & 3.5 \\
\hline \multicolumn{7}{|l|}{ Responsiveness } \\
\hline Service providers are fast and responsive towards tourists & 17 & 39 & 49 & 10 & 0 & 3.5 \\
\hline Great clarity of information provided to tourists & 25 & 50 & 35 & 5 & 0 & 3.8 \\
\hline \multicolumn{7}{|l|}{ Tangibles } \\
\hline $\begin{array}{l}\text { Complete tourist facilities are offered with great } \\
\text { condition }\end{array}$ & 17 & 32 & 46 & 20 & 0 & 3.4 \\
\hline Guaranteed safety and cleanliness of tourist destinations & 14 & 28 & 41 & 29 & 3 & 3.2 \\
\hline Physical appearance of service providers staffs & 14 & 37 & 45 & 17 & 2 & 3.4 \\
\hline
\end{tabular}




\section{Service quality perception}

The assurance dimension consists of two elements: knowledge and skills of service providers in serving tourists (average) and the suitability between services provided with the tourism promotion offered to tourists (average-good). Majority of tourists perceived that service providers could generate trust towards tourists by providing guaranteed high-quality services.

The empathy dimension consists of three elements: attention given individually to tourists (good), the sensitivity of service providers to recognize tourist's needs (average), and the ability of service providers to solve the problems encountered by tourists (standard). Tourists evaluated the empathy dimension as good because service providers paid attention to tourists' specific needs, so tourists feel valued as guests.

The reliability dimension consists of one element: the speed, accuracy, and suitability of service provided to tourists (average). Tourists pointed out that service providers were reliable when delivering accurate and suitable services as expected by tourists.

The responsiveness dimension consists of two elements: speed and responsiveness of service providers (average) and the clarity of information provided to tourists (good). Service providers were responsive to tourist's needs. Tourists agreed that service providers are great in handling travel information as they received the highest mean rating among other service quality elements.

Tangibles dimension consists of three elements: the completeness and condition of tourist facilities (average), cleanliness and security of tourist destinations (standard), and appearance of service providers staffs (average). The tangibles dimension is different from the other four dimensions of service quality because tourists could directly evaluate tangibles aspects as these are in physical form. Many tourists estimated that tangibles aspects were not quite fulfilling as intangible aspects received the lowest mean ratings.

\section{Service Quality Analysis}

Based on observation, tourists perceived some service quality dimensions as excellent, but the same aspects were rated mediocre or even disappointing by some tourists. Service quality as part of the travel process's consumption stage reflects the fulfillment of products/services by service providers towards tourists' needs and the accuracy in conveying service to fulfill tourists' expectations (Tjiptono, 2008). Although most tourists' evaluation towards service quality in Parapat tourist attractions was quite fulfilling, the overall service quality performance in Parapat was only slightly above average. This fact indicates that not all tourists thoroughly enjoyed travel activities in Parapat. Assurance, empathy, reliability, and responsiveness of service provider staff are non-physical aspects of service quality, which are considered quite fulfilling towards most of the Parapat tourist's expectations. Whereas dimension of tangibles are physical aspects of service quality considered inadequate for many Parapat tourists with the lowest mean rating (significantly different from the other four dimensions), implying the improvement in tangible's service quality element is an important issue that requires attention from tourism stakeholders.

The number of respondents with fulfilled expectations is 86 out of 115 people (74.8\%). In comparison, the number of respondents who feel satisfaction on a scale of 3 (quite satisfied) to a scale of 5 (very satisfied) is 113 people $(98.2 \%)$. Tourists' perception and evaluation towards service quality determine the satisfaction that tourists feel, as high-quality service tends to increase tourist satisfaction towards travel destination (Khuong \& Phuong, 2017). Services provided in Parapat tourist destinations fulfill most of the tourist's expectations; hence tourists feel the joy as the embodiment of a positive affective image towards Parapat tourist destination. However, current Parapat tourism services could not provide satisfaction for all Parapat tourists, so both intangibles and tangibles' dimensions of service quality in Parapat tourist destinations must be improved. The improvement of service quality dimensions as listed in figure 3, i.e., (1) providing professional training programs that encourage employees to deliver high-quality service to tourists (intangibles dimension), (2) rearrangement of tourist-related facilities, especially restaurant and souvenir shops, (3) cleanliness of tourist destinations, and (4) ensure of service provider staff's appearance. 


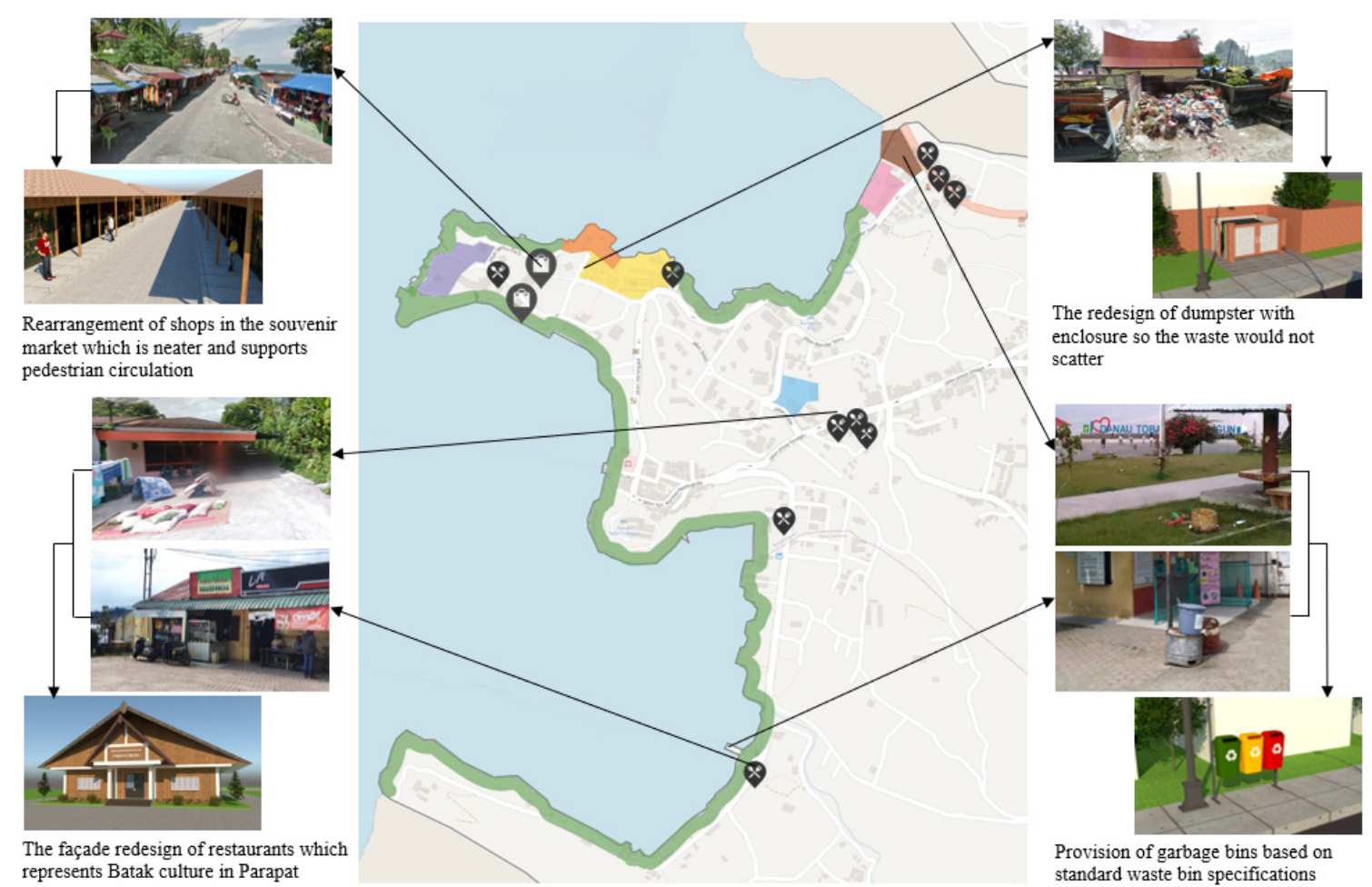

Figure 3. Improvement of tangibles dimension of service quality in Parapat tourist destinations

$97.4 \%$ of respondents formed a positive image towards Parapat after completing their travel activities. A tourist destination's overall appearance consists of cognitive image and affective image. The cognitive image reflects the traveler's knowledge, recognition, beliefs, thoughts, and awareness towards each attribute of the tourist destination. In contrast, the affective image represents feeling and perception as a tourist's emotional interpretation towards a tourist destination (Beerli \& Martin, 2004). In addition to forming satisfaction as the positive affective image (emotional understanding) towards Parapat, tourists also perceive knowledge and evaluation of Parapat tourist destinations attributes, especially service performances that directly contribute to the cognitive image of Parapat (figure. 4). Hence, service quality is considered a significant determinant of tourist satisfaction and the overall appearance of Parapat.

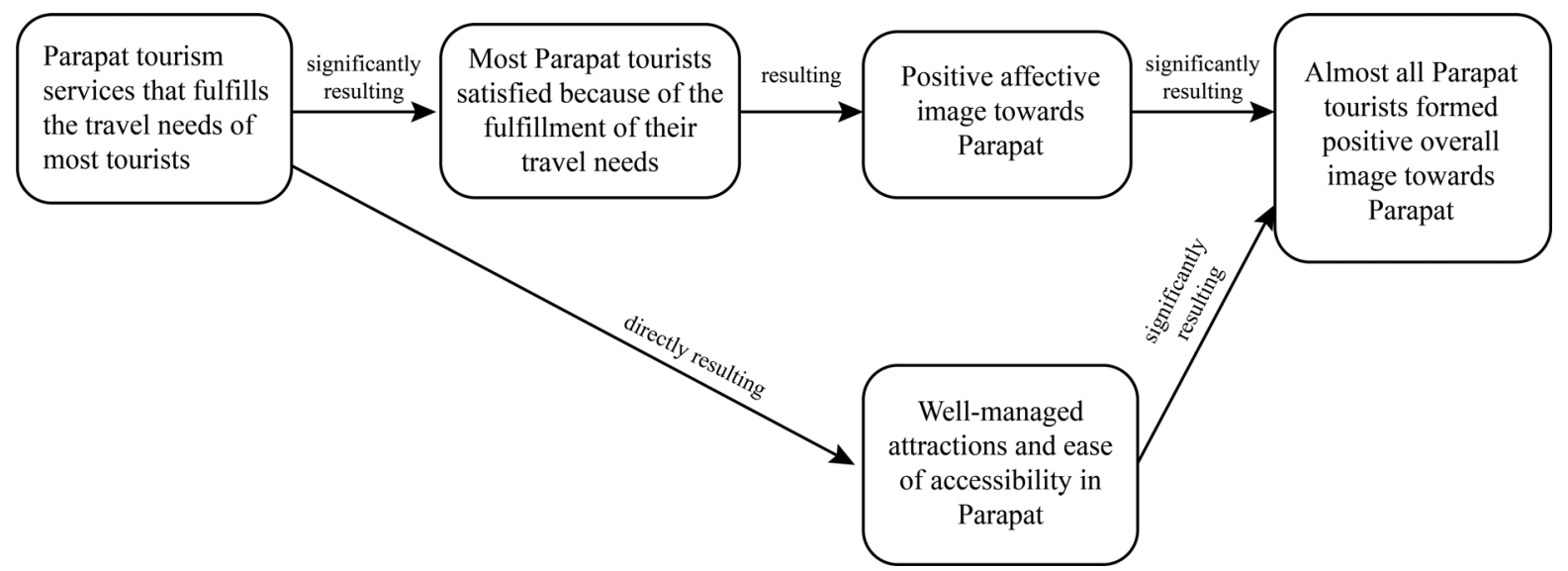

Figure 4. The influence of service quality towards image of Parapat

\subsection{Tourist Satisfaction towards Image of Parapat}

\section{Fulfillment of tourist's demand and needs}

The majority of respondents (74.8\%) stated that the tourism service provided in Parapat met the respondent's expectations (supply meets demand). In comparison, the remaining respondents $(25.2 \%)$ stated that the service could not fulfill their travel needs. From a tourist's behavioral perspective, the satisfaction level results from the post-consumption stage in the travel process. Tourists will be delighted when service providers can provide 
products and services more than expected by tourists (Tjiptono, 2014). Delivering high-quality products and services in Parapat will fulfill the tourists' travel needs. Most tourists feel satisfied, which indicates that Parapat tourism services could meet most of the tourist's expectations towards tourist attractions in Parapat. However, not all tourists are confident because tourism service in Parapat could not fulfill some tourist's desires/needs.

\section{Tourist's Level of Satisfaction}

Most tourists (53.9\%) were more than satisfied with tourist destinations in Parapat, but Parapat tourism successfully delivered a high level of satisfaction towards $10.4 \%$ out of 115 tourists. $33.9 \%$ of tourists perceived sufficient satisfaction, but $1.7 \%$ of tourists were partly satisfied with Parapat tourist destinations. Based on the level of tourist satisfaction from 3 (happy) to a scale of 5 (very satisfied), $98.3 \%$ of tourists perceived satisfaction after completing travel to Parapat. Chen \& Tsai (2007) stated that tourist satisfaction is a form of tourist's pleasure as positive emotion arises from their travel experience based on their expectations or travel needs. Satisfaction is measured over the performance of products and services in a tourist destination so that tourists will feel pleasure; the products and services provided can fulfill tourists' needs. The level of tourist satisfaction can be measured based on how much their travel experience in Parapat fulfills the tourist desires. The fact that most tourists were more than satisfied and some tourists were even highly satisfied indicates that Parapat tourist destinations can offer products or services more than expected by tourists.

Table 4. Parapat tourists' satisfaction level

\begin{tabular}{llll}
\hline \multirow{2}{*}{ Satisfaction level } & \multicolumn{2}{l}{ Travel needs fulfillment } & \multirow{2}{*}{ Total } \\
\cline { 2 - 3 } & fulfilled & Not fulfilled & \\
\hline Very satisfied & 12 & 0 & 113 \\
More than satisfied & 62 & 0 & \\
Satisfied & 12 & 27 & 2 \\
Partly satisfied & 0 & 2 & \\
Dissatisfied & 0 & 0 & 115 \\
Total & 86 & 29 & \\
\hline
\end{tabular}

\section{Tourist Satisfaction Analysis}

The number of tourists whose expectations were able to be fulfilled by services provided was 86 out of 115 respondents (74.8\%), whereas the number of tourists who perceived satisfied from a scale of 3 (comfortable) to a scale of 5 (very satisfied) was 113 people out of 115 respondents $(98.2 \%)$. The difference from both data showed as many as 27 people (23.4\%) perceived satisfaction though the services did not meet their expectations. The total number of tourists who feel satisfaction is 113 people from 115 respondents $(98.2 \%)$. Although Parapat tourism services could not fulfill some tourists' expectations, they can still achieve satisfaction. Other than services provided as amenities, other tourism attributes also positively influenced their travel experience. Hence almost all tourists achieved satisfaction.

The number of tourists who perceived satisfaction was 113 people $(98.2 \%)$, and 112 people (97.4\%) formed a positive image towards Parapat. A comparison of both data shows a direct linkage between tourist satisfaction and destination image. The level of pride felt by tourists will significantly affect the positive image formed towards Parapat tourism destinations (figure 5). Tourist satisfaction indicates how well a tourist destination is currently meeting tourists' needs related to the quality of tourist products and services received by tourists, which significantly influences tourists in shaping a positive image towards the tourist destination (Martaleni, 2017). Service quality directly affects tourist satisfaction because the quality of service that exceeds tourists' expectations will give tourists very high satisfaction.

The affective image represents feeling and perception as a tourist's emotional interpretation towards a tourist destination (Beerli \& Martin, 2004). Satisfaction felt by Parapat tourists is the embodiment of a positive affective image that forms the overall appearance of Parapat. The higher the tourists' level of joy, the more positive the tourists' image towards tourist destinations in Parapat. A positive image can affect tourist's intention to revisit and give out recommendations to potential tourists, as it increases the number of tourist visits to Parapat. Therefore, Parapat tourism service providers must always strive to form satisfaction towards tourists through a positive travel experience. Parapat has a positive image in the eyes of local and foreign tourists; thus, many tourists will visit Parapat. 


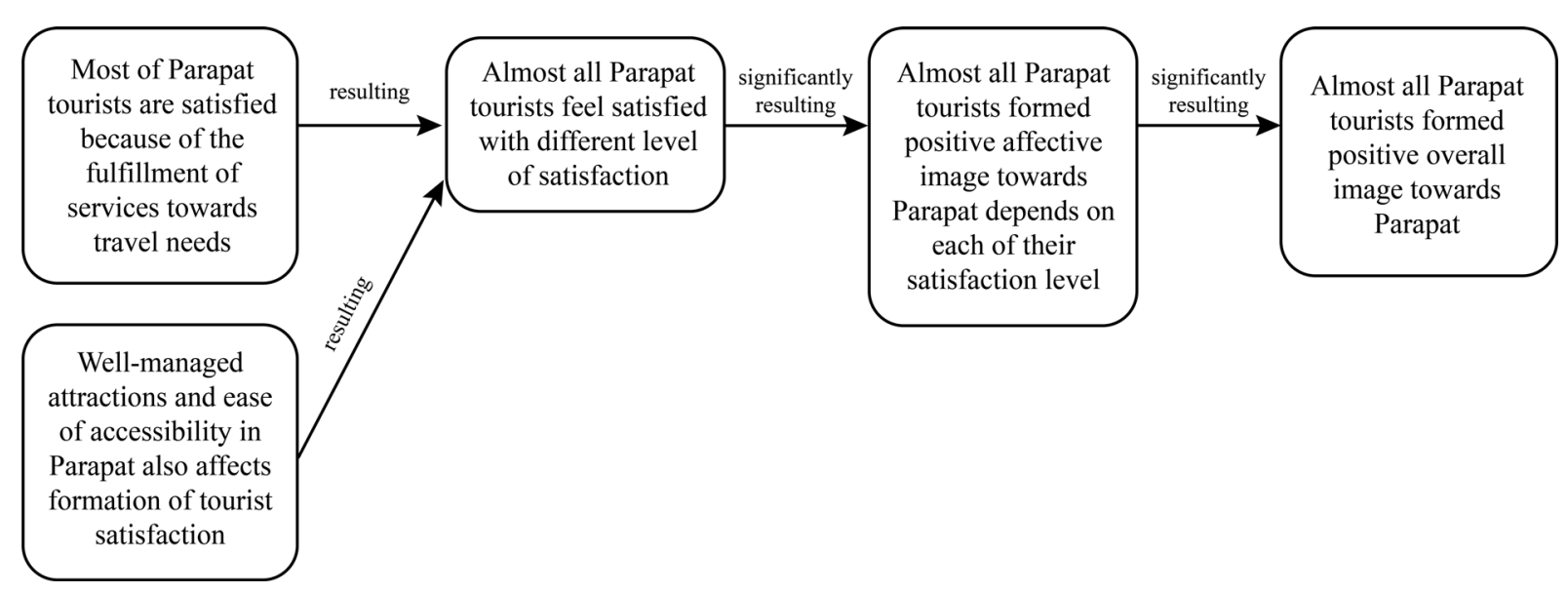

Figure 5. The influence of tourist satisfaction in forming image of Parapat

\subsection{Direct and Indirect Influence towards Image of Parapat}

\section{Image of Parapat through Tourists' Perspective}

Only $13 \%$ of respondents formed a very positive image towards Parapat, $54.8 \%$ of respondents created a positive impression, and $29.6 \%$ of respondents developed an average idea towards Parapat. At the same time, $2.6 \%$ of respondents formed a negative image towards Parapat. A tourist destination's overall appearance is created by cognitive image and affective image. The cognitive image reflects the traveler's knowledge, recognition, beliefs, thoughts, and awareness of each tourist destination attribute. In contrast, the affective image represents feeling and perception as a tourist's emotional interpretation towards a tourist destination (Beerli \& Martin, 2004). The process of establishing a destination image by tourists through tourism experience, according to Manhas, Manrai \& Manrai (2016), can be described in three stages, i.e., pre-consumption stage (travel planning), consumption stage (travel implementation), and post-consumption stage (after travel). The overall image of the Parapat is formed through the steps of tourist's travel experience in Parapat. During the pre-consumption stage, tourists' desire (travel motivation push factors) was linked to Parapat tourism attributes (travel motivation pull factors) that influenced tourists to visit Parapat. Hence, tourists travelled to Parapat believing Parapat's tourist attractions would fulfill their travel needs. During tourists' stay in Parapat (consumption stage), tourism service providers in Parapat provide product services to fulfill tourist's travel needs. The quality of services in Parapat directly determines cognitive image and formation of satisfaction (affective image) towards Parapat. During the post-consumption stage, almost all Parapat tourists were able to feel satisfaction because the tourism attributes, mainly services offered, could fulfill tourists' different travel needs. However, few tourists perceived dissatisfaction and negative image towards Parapat because Parapat tourism attributes could not complete their travel needs.

Tourist satisfaction's level directly and significantly influenced the overall image of Parapat as well (table 5). Satisfaction perceived by tourists will be achieved if service quality can fulfill tourists' travel needs (related to tourist's travel motivation). Although satisfaction is not entirely dependent on service quality, service quality and travel motivation indirectly influenced satisfaction. Hence tourists that perceived satisfaction are most likely to perceive a positive image towards Parapat.

Table 5. Parapat tourists' satisfaction towards Parapat destination image

\begin{tabular}{lll}
\hline \multirow{2}{*}{ Levels } & \multicolumn{2}{l}{ Frequency of Responses } \\
\cline { 2 - 3 } & Satisfaction & Image \\
\hline Very satisfied/very positive & 12 & 15 \\
More than satisfied/more than positive & 62 & 63 \\
Satisfied/Positive & 39 & 34 \\
Partly satisfied/partly positive & 2 & 3 \\
Dissatisfied/negative & 0 & 0 \\
Total & 115 & 115 \\
\hline
\end{tabular}




\section{Direct Influence of Travel Motivation, Service Quality and Tourist Satisfaction towards Image of Parapat}

The number of tourists who perceived satisfaction was 113 people out of 115 respondents (98.2\%), and 112 out of 115 respondents $(97.4 \%)$ stated they would consider revisiting Parapat in the future. Comparison of both data shows that satisfaction significantly influences tourists' intention to revisit Parapat in the future (fig. 6). Tourist satisfaction is considered a critical element to maintain competitive business as a benchmark of successful tourism marketing because it is directly associated with the potential of revisit (Meng, Tepanon \& Uysal, 2008). Tourists who feel satisfaction and form a positive image towards Parapat are likely to revisit Parapat to re-experience the pleasant travel experience in Parapat. Return visits by satisfied tourists increase the number of tourists visit in Parapat, so Parapat tourism stakeholders must ensure that tourists perceived satisfaction and a positive image towards Parapat.

\section{Indirect Influence of Travel Motivation, Service Quality and Tourist Satisfaction towards Image of Parapat}

The number of tourists who perceived satisfaction was 113 people out of 115 respondents (98.2\%), and 111 out of 115 respondents (96.5\%) would recommend Parapat tourist destinations to others, but 3.5\% of respondents would not give out recommendations. Tourist satisfaction is considered a critical element to maintain competitive business as a benchmark of successful tourism marketing because it is directly associated with choosing a tourist destination (Meng, Tepanon \& Uysal, 2008). Tourists who perceived satisfaction towards tourist destinations in Parapat tend to give recommendations for others to visit Parapat.

$55.7 \%$ of respondents obtained information about tourist destinations in Parapat through recommendations given by past travelers who had visited Parapat. Tourism promotion manifested the tourist destination image through official promotional media or word-of-mouth from past travelers (Akroush \& Jraisat, 2016). The positive image of Parapat formed by tourist satisfaction influenced by travel motivation and service quality indirectly influences potential tourists to visit Parapat. These potential tourists will establish a positive/negative image towards Parapat tourist attractions based on their own travel experience (figure 6). However, the decrease in the number of Simalungun Regency tourist visits by $7 \%$ from $30.9 \%$ (2018) to $23.9 \%$ (2019) indicates that some dissatisfied tourists made them unwilling to recommend Parapat to others, or probably shared their unsatisfactory travel experiences that would prevent potential tourists from visiting Parapat. As discussed in the previous section, word-of-mouth from past travelers holds significant power in attracting potential tourists to visit Parapat. The word-of-mouth shared by past travelers is considered vital towards tourism destination's number of visits; consequently, Parapat tourism stakeholders must strive to give all tourists satisfaction to create a positive overall image that can be effectively shared with the public and thus attract more tourists.

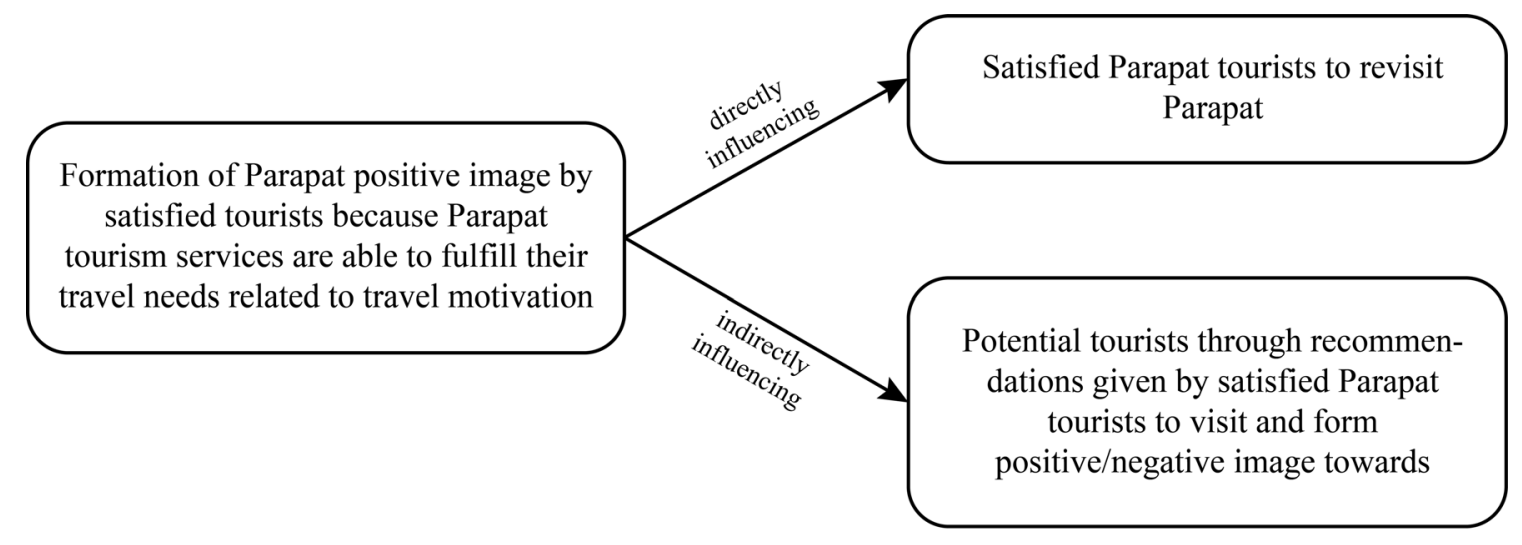

Figure 6. The direct and indirect influence of travel motivation, service quality and tourist satisfaction towards the image of Parapat

\section{Implications and Conclusions}

The present study contributes positively to the development of theory in tourism contexts regarding tourism development and marketing. The research results also contributed to extending the understanding of factors that influence tourists' behavior pattern in travel decision making. Correspondingly, this study may serve as the launching point for others to generate future research in tourism with a complex model that incorporates the linkage between tourist behavior and destination image. Furthermore, the present study findings should encourage Parapat tourist destination stakeholders to modify and devise current strategies to meet the needs of tourists through a behavioral approach. 
Accordingly, this study constructed a comprehensive model concerning destination image and the determinants (travel motivation, service quality, and tourist satisfaction) from the tourist's perspective. The study's structural relationship between all variables was observed and analyzed using data obtained from the tourist questionnaire survey in Parapat. It is concluded that all the constructs were indeed interrelated in establishing destination image.

The tourist destinations frequently visited by tourists in Parapat are Lake Toba, Pasir Putih Beach, and Inna Parapat Beach because they offer more attributes than other Parapat tourist destinations. With the aim that tourists will want to visit every tourist destination in Parapat, tourism stakeholders should provide more accommodation in Indah Permai Beach, Free Beach, Pesanggrahan Bung Karno House, and HKBP Parapat Church. Facilities and services offered, ease of accessibility and contribution of tourism stakeholders can support Parapat tourist destinations' valuable attractions.

This study found that "relaxation" was essential to Parapat tourists concerning all the push factors of tourists' travel motivation. On the other hand, "attractions" was not surprisingly the most favourable factor among all the pull factors, as Parapat is famous for its natural and cultural attractions. Tourists thought that their travel needs could be fulfilled through travel activities in Parapat; hence tourists form a strong motivation to travel to Parapat. The service provider's quality of service in Parapat tourist destinations, in general, was able to fulfill most tourists' travel needs, directly resulting in tourist satisfaction formation. Although service quality is considered a significant determinant of tourist satisfaction, satisfaction formation did not only depend on the services provided. Other tourism attributes such as the variety of attractions in well-managed tourist destinations, easy accessibility, and involvement of tourism stakeholders also contributed to establishing satisfaction. Almost all tourists feel satisfied with Parapat tourism, even tourists whose travel needs were not fulfilled by the service provided. The perceived satisfaction is regarded as the positive affective image, while their positive evaluation towards Parapat tourism attributes is regarded as a positive cognitive image. Hence, almost all of the tourists formed a positive overall image towards tourist destinations in Parapat.

Thus, it is concluded that tourism's underlying role in providing service following tourists' expectations (travel motivation) and service quality as one of the main tourist attributes is considered a significant determinant of tourist's satisfaction and positive overall image. In other words, travel motivation and service quality indirectly influenced destination image, whereas satisfaction directly influenced destination image. Furthermore, satisfaction influenced tourists' future behavior. Highly satisfied tourists were most likely to repeat the visit (directly motivate them to return in the future) and spread positive information by word of mouth (indirectly motivate potential tourists to travel to the related tourist destination). Based on this study, tourist recommendations are the most effective form of Parapat tourism promotion in recent years, so a high level of satisfaction and a favourable image should be brought out towards every tourist to increase Parapat number of visits.

However, two significant issues need to be addressed. The first issue is related to tourism marketing as a strategy to attract tourists. It is of primary importance that tourism marketers carry out promotions to attract potential tourists to be aware of and visit the attractions offered in Parapat. Regarding the information sources, tourism promotion carried through advertising campaigns and brochures, social media, and the internet (communication media) has proven to form an initial image towards potential tourists effectively. Tourism marketers should use this method, as long as tourism marketers ensure that the messages transmitted coincide with the desired positive image of Parapat tourism to trigger potential tourists' motivation to travel. However, the current Parapat tourism promotion mainly involved only Lake Toba. In a broader tourism marketing strategy, tourism marketers should promote the uniqueness of every tourist destinations in Parapat. It gives more options for potential tourists to convince them in their travel decision-making.

The second issue regarding service quality is the critical aspect of establishing tourist satisfaction and improving the positive overall image. Concerning other constructs in this concept, "amenities" as one of the pull factors were not considered the main reason is attracting most Parapat tourists. As one of the main attributes provided by tourist destinations, service quality becomes the main concern because apparently, it wasn't the primary consideration for most tourists to come to Parapat. This indicates Parapat tourism products and services were not as appealing enough to attract potential tourists. Concerning tourist's critical evaluation towards service quality, both intangible and tangible dimensions should be improved, i.e., provide professional training to improve service provider staffs' skills (intangible dimension), condition of tourist facilities, arrangement and cleanliness of tourist destinations, and staff appearance. The improvement in service quality is essential for tourists to consider their travel experience valuable, so higher satisfaction would occur. Furthermore, the benefits of future positive behavior could be brought out. 


\section{Limitations and Future Research}

This study has potential limitations. Although this study attempted to obtain random samples, the respondents were local tourists between 17-30 years old. Accordingly, the results are not generalizable to the diverse population of tourists in Parapat. Future research should survey samples with a greater range of age groups and involve foreign tourists as participants in the study. Another limitation is that the present study primarily focused on the causality between tourists' travel motivation, service quality, and tourists' satisfaction towards tourist destination image. It is important to note that tourist destination should improve their service quality based on tourists' needs. Thus, future research should pursue deeper investigations concerning the tourists' behavior by incorporating the measures of tourists' psychological characteristics (e.g., personality, environcognitive concern, temperament, and satisfaction of needs) and tourist attributes that may enhance the travel experience. These may provide more substantial evidence of causality between each of these constructs.

\section{Acknowledgements}

This research is a preliminary study towards a public policy on tourism as a whole in the Lake Toba area of Indonesia. This research is supported by the Deputy for Research and Development Strengthening; Ministry of Research and Technology / National Agency for Research and Innovation in the Fiscal Year 2020 following Amendment to Research Contract Number: 11 / AMD / E1 / KP.PTNBH / 2020, 11 May 2020. During the research process, researchers acknowledged the community's support in gathering observational data and questionnaires. Researchers would like to thank the Department of Culture and Tourism of Parapat in Girsang Sipanganbolon District who helped in the process of obtaining secondary data to complete the required primary data. Sustainable Tourism Observatory of Lake Toba and Monitoring Center Sustainable Tourism Observatory (MCSTO) of Universitas Sumatera Utara also participated in supporting the completion of the research so that it is worthy of publication.

\section{References}

Akroush, M. N., Jraisat, L. E., Kurdieh, D. J., AL-Faouri, R. N., \& Qatu, L. T. (2016). Tourism service quality and destination loyalty-the mediating role of destination image from international tourists' perspectives. Tourism Review, 71(1), 18-44. https://doi.org/10.1108/TR-11-2014-0057

Beerli, A., \& Martin, J. D. (2004). Factors influencing destination image. Annals of tourism research, 31(3), 657-681. https://doi.org/10.1016/j.annals.2004.01.010

Chen, C. F., \& Tsai, D. (2007). How destination image and evaluative factors affect behavioral intentions? Tourism management, 28(4), 1115-1122. https://doi.org/10.1016/j.tourman.2007.06.007

Chi, C. G. Q., \& Qu, H. (2008). Examining the structural relationships of destination image, tourist satisfaction and destination loyalty: An integrated approach. Tourism management, 29(4), 624-636. https://doi.org/10.1016/j.tourman.2007.06.007

Gnanapala, W. K. A. C. (2012). Travel Motivations and Destination Selection: A Critique. International Journal of Research in Computer Application \& Management, 2(1), 49-53.

Jang, S., Bai, B., Hu, C., \& Wu, C. M. E. (2009). Affect, travel motivation, and travel intention: A senior market. Journal of Hospitality \& Tourism Research, 33(1), 51-73. https://doi.org/10.1177/1096348008329666

Katsoni, V. (2014). The strategic role of virtual communities and social network sites on tourism destination marketing. e-Journal of Science \& Technology, 9(5). Retrieved from https://e-jst.teiath.gr/issues/issue_38/Katsoni_38.pdf

Kayat, K., \& Abdul Hai, M. (2014). Perceived service quality and tourists' cognitive image of a destination. Anatolia, 25(1), 1-12. https://doi.org/10.1080/13032917.2013.814580

Khan, M. J., Chelliah, S., \& Ahmed, S. (2017). Factors influencing destination image and visit intention among young women travelers: role of travel motivation, perceived risks, and travel constraints. Asia Pacific Journal of Tourism Research, 22(11), 1139-1155. https://doi.org/10.1080/10941665.2017.1374985

Khoo-Lattimore, C., Mura, P., \& Yung, R. (2019). The time has come: A systematic literature review of mixed methods research in tourism. Current Issues in Tourism, 22(13), 1531-1550. https://doi.org/10.1080/13683500.2017.1406900

Khuong, M. N., \& Phuong, N. T. (2017). The Effects of Destination Image. Perceived Value. https://doi.org/10.18178/ijtef.2017.8.5.568

Kotler, P., Keller, K. L., \& Lu, T. (2009). Marketing management in China. Singapore: Prentice Hall Pearson. 
Manhas, P. S., Manrai, L. A., \& Manrai, A. K. (2016). Role of tourist destination development in building its brand image: A conceptual model. Journal of Economics, Finance and Administrative Science, 21(40), 25-29. https://doi.org/10.1016/j.jefas.2016.01.001

Martaleni, M., \& Gunadi, G. (2017). Analysis of Tourism Destination Image Attributes: a Case of Batu City, Indonesia. e-Repository Dosen Universitas Gajayana Malang. https://doi.org/10.24034/j25485024.y2014.v18.i2.145

Meng, F., Tepanon, Y., \& Uysal, M. (2008). Measuring tourist satisfaction by attribute and motivation: The case of a nature-based resort. Journal of vacation marketing, 14(1), 41-56. https://doi.org/10.1177/1356766707084218

Pitana, I. G., \& Gayatri, P. G. (2005). Sociology of Tourism: Sociological studies of the structure, systems and impacts of tourism. Indonesia, Yogyakarta: Penerbit Andi.

Setyaningsih, S., \& Murwatiningsih, M. (2017). The Influence of Motivation, Promotion and Destination Image on Tourist Satisfaction through Tourist Decision. Management Analysis Journal, 6(2), 123-133. https://doi.org/10.15294/maj.v6i2.5579

Suwena, I. K., Widyatmaja, I. G. N., \& Atmaja, M. J. (2010). Basic knowledge of tourism science. Udayana University Press. Indonesia, Bali : Pustaka Larasan.

Tjiptono, F. (2008). Marketing strategy. Indonesia, Yogyakarta: Penerbit Andi.

Tjiptono, F. (2014). Service Marketing-Principles. Application, and Research. Indonesia, Yogyakarta: Penerbit Andi.

Visser, G. (2009). Tourism geographies and the South African National Research Foundation's Researcher Rating System: international connections and local disjunctures. Tourism Geographies, 11(1), 43-72. https://doi.org/10.1080/14616680802643243

\section{Copyrights}

Copyright for this article is retained by the author(s), with first publication rights granted to the journal.

This is an open-access article distributed under the terms and conditions of the Creative Commons Attribution license (http://creativecommons.org/licenses/by/4.0/). 